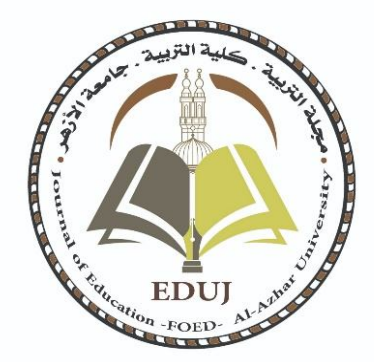

\title{
E-learning Challenges in Light of the Corona Pandemic: Perspectives of Physical Education Teachers in the Governorate of Karak
}

\author{
Dr. Jamal Ali Rababah \\ Mu'tah University / College of Sports Sciences, Department \\ of Physical Education, Jordan
}


تحديات التعليم الاككتروني في ظل جائحة كورونا من وجهة نظر معلمي

التربية الرياضية في الكرك

جمال علي سعيد ربابعـاه

قسم التربية الرياضية، كلية علوم الرياضية، جامعة مؤتة، المملكة الأردنية الهاشمية.

البريد الالكتروني: Lilian_jamal@yahoo.com

المستخلص : (1)

هدفت الدراسـة التعرف الي تحديات التعليم الالكتروني في ظل جانحة كورونا من وجهة

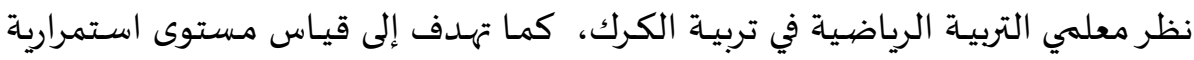

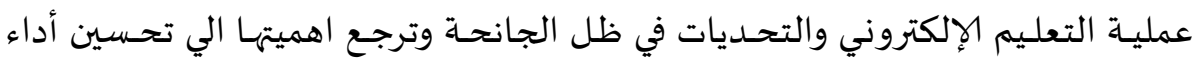

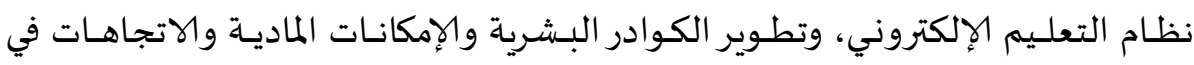
انتقاء أنماط التعليم المتبعة ووضع الخطط المستقبلية للتوجها للتعلم الإلكتروني كبديل للتعلم وجهاً لوجـاه، استخدم الباحث المنهج الوصيفي، تكونت عينـة الدراسـة من (132)

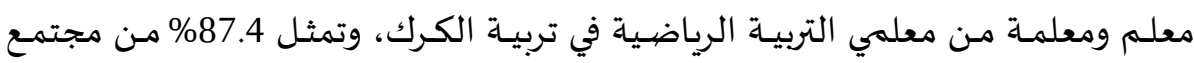

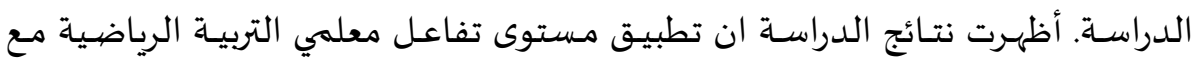

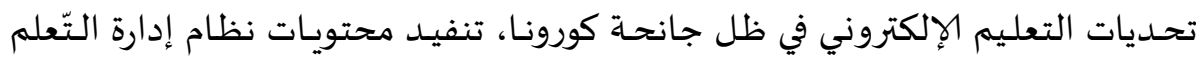

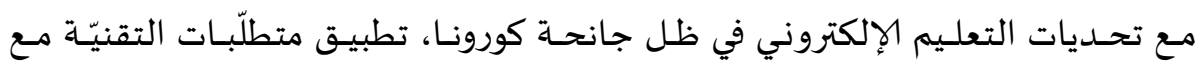

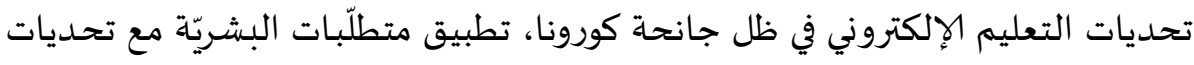

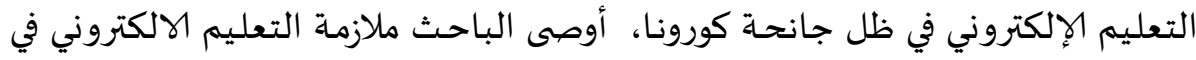
ظل جانحة كورونا، وتطبيق التعليم الهجين في عملية التعليم والتعلم، تطبيق التحديات الإلكتروني في عمليتي التعليم والتعلم.

الكلمات الافتتاحية: التعليم الإلكتروني، فيروس كورونـا (كوفيد-19)، تحديديات التعليم الإلكتروني،معلمي التربية الرياضية:الإية 


\title{
E-Learning Challenges in Light of the Corona
}

Pandemic: Perspectives of Physical Education Teachers in the Governorate of Karak

Jamal Ali Rababah

Department of Physical Education, College of Sports Sciences, , Mu'tah University, Jordan.

Email: Lilian_jamal@yahoo.com

\begin{abstract}
The study aimed at investigating the challenges of E-learning in light of the Corona pandemic from the perspective of physical education teachers in the city of Karak. Moreover, the study aimed at measuring the level of continuity of the E-learning process and the challenges in light of the pandemic. The significance of the study stems from being an original attempt to improve the performance of the E-learning system, develop human staffs, capabilities and trends in selecting the followed educational patterns, in addition to develop future plans for E-learning as an alternative to face-to-face learning. The researcher used the descriptive approach. The sample of the study consists of (132) teachers (males and females) of physical education in Karak. The sample of the study represents $87.4 \%$ of the study population. The results of the study showed that the level of implementation of physical education teachers' interaction with the challenges of Elearning in light of the Corona pandemic, the contents of the learning management system, the technical requirements, and human requirements. The researcher recommended pursuing electronic education in light of the Corona pandemic, applying blended teaching in the education process and applying electronic challenges in the teaching and learning processes.
\end{abstract}

Keywords: E-Learning - Coronavirus (Covid-19) - E-Learning Challenges Physical Education Teachers. 


\section{Introduction}

The increasing interest in the education sector and in the development plans of countries polices comes as a result to its ability to raise efficiency and provide learners with knowledge, information and skills to keep pace with global scientific development. After the emergence of the Corona pandemic and the spread of the epidemic around the world, educational institutions were closed and the world started looking for alternative solutions and focusing on E-learning (distance learning) as an attempt by the Ministry of Health and the Ministry of Education and Higher Education to control the situation, maintain the continuity of education and protect it as a social necessity. The information technology and the internet have opened the way to access knowledge and educational quality to enable learners to improve their life, professional and scientific skills and take advantage form the privileges of the E-learning (programs, systems and applications) (Yahyaoui, 2017: 12).

The pandemic affected millions of students worldwide. The sudden transformation in the teaching and learning activities into virtual modalities was carried out in order to continue the academic courses while avoiding people gathering and the potential risk of the spread of infection

Distance education becomes an urgent necessity, especially with the spread of epidemics and viruses that require social distancing. It, also, requires information systems, websites to support a parallel education that covers the deficit created by the pandemic that shook the world through challenges and experiences (Al-hay, 2017: 24)

The spread of the Corona virus has led to a sudden and strong shock in societies and countries, a shock that has never been witnessed during the previous centuries. The world was paralyzed lost its balance, its economy, its development, business and distanced between individuals socially. The pandemic aroused fear and caution in societies, leaving clear effects on the economy, politics, society, and even on various aspects of life (Hamdan, 2020: 23).

Despite the growth of distance and online learning during and before the Corona pandemic, this trend faces great challenges that began with the difficulty of accessing the internet and the technological tools necessary for the digital learning process which widened the gap and inequality at the level of one society and between different countries (Bouaghous, 2020: 1).

According to Ghazi (2020: 54), Open Distance Learning (henceforth ODL) or Electronic-Learning (henceforth EL) is a type of learning that has always been discussed to integrate it into the educational process before the corona pandemic. However, it became an alternative and an urgent need to continue teaching in conditions that impose physical distancing.

Koumi (2018) states that E-learning came as a result of technological developments, especially, after the educational process 
was directly affected by the automation of the industry, the development of "Artificial Intelligence", "Internet of Things", technology as well as the information technology revolution which broke into the classroom and became an integral part of it.

On their side, Asim and Al Rababaa (2020) state that E-learning is a modern educational trend that is necessary to find the best methods and the most successful means to provide an appropriate interactive learning environment to attract students' interest, encourage them to learn, exchange views and dialogue, so that the students are not only recipients of information, but also positive participants. Furthermore, the students will be creative, experienced, good researchers about information and knowledge by all possible means. They will be able to use scientific procedures, such as observation, understanding, analysis, structuring, measurement, reading data, and deduction, under the supervision of a school, directing it and evaluating it.

The process of integrating information technologies (computer, Internet, programs and multimedia in the teaching process) is one of the most successful means to create environments rich in teaching, learning and training to meet the needs and interests of students, and to enhance their motivation and the service of the teaching process. This will contribute in upgrading its outputs and its interaction with the course of this process in light of the urgent changes in the world caused by the pandemic of Corona. Moreover, it contributes to the developments in technological revolution and knowledge revolution in the technologies of the digital age (artificial intelligence). (Asim, 2020: 2)

Needless to say that E-learning has an important and fundamental role in the success of the teaching process in light of the great technological development and with the spread of modern means of communication such as computers, Internet, and multiple media, such as: sound, image, and video. These are the means that allowed a large number to receive education easily and with less time and effort. In the light of the pandemic that the whole world is suffering from nowadays, the educational institutions suddenly found themselves forced to switch to distance learning to ensure the continuity of the teaching and learning process through the use of Internet, smartphones and computers to communicate remotely with students in the governorate of Karak through means of communication that were not used before. Physical education teachers also communicated with students in different ways using modern distance education techniques. 


\section{Significance of the Study}

The significance of the study can be summarized as follows:

1. The results of this study will be useful for the educational district of the Directorate of Education in Karak.

2. It will improve the performance of the E-learning system, developing human staffs, capabilities and it will help in selecting the teaching patterns used.

3. It will establish future plans towards E-learning as an alternative to face-to-face learning.

4. It will make use of the study tool in measuring the effectiveness of the E-learning system in schools, universities and E-learning institutions.

5. The significance of the study stems from being a study conducted on a contemporary realistic issue which is the spread of the Coronavirus.

6. The results of this study can be used in future studies to tackle upcoming crises.

\section{Objectives of the study}

The study aims at achieving the following objectives:

1. Revealing the challenges of E-learning in light of the Corona pandemic from the perspective of physical education teachers.

2. Measuring the level of continuity of the E-learning process and the challenges in light of the pandemic.

3. Investigating the usefulness of E-learning by studying the sample, namely physical education teachers

4. Identifying the level of interaction between students and physical education teachers with E-learning.

\section{The Questions of the Study}

The study seeks to answer the following questions:

1. What are the technical requirements of E-learning in light of the Corona pandemic?

2. What are the human requirements of E-learning in light of the Corona pandemic?

3. What are the contents of a learning management system of Elearning in light of the Corona pandemic?

4. What is the level of physical education teachers' interaction of Elearning in light of the Corona pandemic? 


\section{Methodology}

The study relies on the descriptive and analytical method.

\subsection{The population of the Study}

The population of the study consisted of (151) teachers (males and females) in Directorate of Education of Karak for the academic year 2020/2021.

\subsection{The Sample of the Study}

As mentioned, the study was implemented randomly on a sample consisting of (132) male and female physical education teachers in Karak education. The sample of the study represented $(87.4 \%)$ of the community in the Directorate of Education. It was divided as follows: (66) male physical education teachers and (66) female physical education teachers.

\subsection{The tool of the Study}

To achieve the objectives of this study, the researcher distributed a questionnaire, consisting of (36) paragraphs on the teachers working in the Education Directorate in Karak Governorate who practiced Elearning during the pandemic. The questionnaire was developed based on similar previous studies conducted on the same topic (Asim and Rababah 2020, Yamen 2008 and Silverman S. 2010, Stephanie Bennet 2013).

The questionnaire consisted in its final form of (36) paragraphs using the scale (agree, agree sometimes and disagree). The questionnaire tackled four aspects:

1. Technical requirements: This field contains (12) paragraphs.

2. Human requirements: This field contains (7) paragraphs.

3. The contents of the learning management system: This field contains (7) paragraphs.

4. The level of interaction of physical education teachers with Elearning: This area contains (10) paragraphs.

\subsection{Instrument Validity}

The questionnaire was presented, in its initial form, to seven arbitrators with experience and competence in the field of scientific research and teaching in the field of physical education with the aim of judging the study tool (the questionnaire), and knowing the clarity and comprehensiveness of its paragraphs to all aspects of the challenges of E-learning in light of the pandemic as well as the appropriateness of formulating the paragraphs. The researcher modified the questionnaire in light of the opinions of the arbitrators, and the validity of the questionnaire ranged between $(0.78 \%$ and $0.92 \%)$. 


\subsection{Instrument Reliability}

A pilot study was conducted on a sample consisting of (30) teachers of physical education in the Directorate of Education in Karak. Cronbach's Alpha test was used to test the reliability of the questionnaire. The values of reliability coefficients for the questionnaire aspects ranged between (0.654 and 0.798).

\section{Table No.1}

The validity and reliability of the questionnaire in the context of the challenges of E-learning in light of the Corona pandemic from the perspective of physical education teachers in Directorate of Education in Karak

\begin{tabular}{ccc}
\hline Aspect & Validity & Reliability \\
\hline Technical Requirements & $\% 0.78$ & $\% 0.758$ \\
Human Requirements & $\% 0.79$ & $\% 0.654$ \\
$\begin{array}{c}\text { Contents of Learning } \\
\text { management System }\end{array}$ & $\% 0.88$ & $\% 0.754$ \\
$\begin{array}{c}\text { Level of Interaction between } \\
\text { Teachers of Physical Education }\end{array}$ & $\% 0.798$ & $\% 0.92$ \\
\hline
\end{tabular}

Table no. 1 and figure No. 1 show that the values of reliability coefficients for the questionnaire aspects ranged between $(0.654$ and $0.798)$, whereas the values of the validity coefficients ranged between (\%0.92 and \%0.78).

\section{Discussion and Findings}

\subsection{Results}

\section{The first question:}

What are the technical requirements of E-learning in light of the pandemic?

Table No.2 shows the technical requirements of E-learning in light of the pandemic 


\begin{tabular}{|c|c|c|c|}
\hline \multicolumn{3}{|c|}{ العدد: (190)، الجزء ( 5)، أبريل لسنة 2021م } & كلية التربية بالتقاهرة \\
\hline \multicolumn{3}{|c|}{ Table No.2 } & $\mathrm{N}=132$ \\
\hline \multirow{13}{*}{ 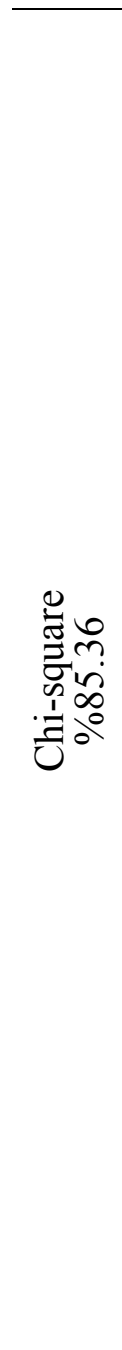 } & $\begin{array}{l}\text { Standard } \\
\text { Deviation }\end{array}$ & $\begin{array}{l}\text { Arithmetic } \\
\text { mean }\end{array}$ & $\begin{array}{c}\text { First Aspect: Technical } \\
\text { Requirements }\end{array}$ \\
\hline & 0.90 & 2.55 & $\begin{array}{l}\text { Availability of infrastructure and } \\
\text { the needs of the learner from } \\
\text { various learning resources }\end{array}$ \\
\hline & 0.82 & 2.47 & $\begin{array}{l}\text { Availability of virtual classes } \\
\text { along with the traditional classes }\end{array}$ \\
\hline & 0.67 & 2.43 & $\begin{array}{l}\text { Availability of software for } \\
\text { managing E-learning }\end{array}$ \\
\hline & 0.34 & 2.35 & $\begin{array}{l}\text { Availability of tools and means } \\
\text { for training }\end{array}$ \\
\hline & 0.57 & 2.45 & $\begin{array}{l}\text { Training the teachers to use E- } \\
\text { learning during the pandemic. }\end{array}$ \\
\hline & 0.90 & 2.55 & $\begin{array}{l}\text { The techniques used in E-learning } \\
\text { must be effective and } \\
\text { comprehensive }\end{array}$ \\
\hline & 1.55 & 2.70 & $\begin{array}{l}\text { Smooth transition from traditional } \\
\text { classes to E-learning }\end{array}$ \\
\hline & 1.39 & 2.64 & $\begin{array}{l}\text { Satisfaction about the use of E- } \\
\text { learning as an alternative to the } \\
\text { traditional education }\end{array}$ \\
\hline & 1.41 & 2.62 & $\begin{array}{l}\text { Sending and receiving education } \\
\text { materials without technical } \\
\text { obstacles }\end{array}$ \\
\hline & 1.40 & 2.50 & $\begin{array}{l}\text { Availability of electronic training } \\
\text { courses for teachers to explain } \\
\text { how to use E-learning }\end{array}$ \\
\hline & 1.34 & 2.28 & $\begin{array}{l}\text { Teachers have sufficient skills to } \\
\text { design and produce effective } \\
\text { electronic content }\end{array}$ \\
\hline & 0.67 & 2.43 & $\begin{array}{l}\text { Availability of E-learning system } \\
\text { that can provide } \\
\text { communication } \\
\text { direct } \\
\text { administration, teacher } \\
\text { student. }\end{array}$ \\
\hline
\end{tabular}

\section{Figure 2}

Table 2 and Figure 2 show that the value of chi-square $=85.36 *$ chisquare tabular at a degree of freedom (5) and an error ratio (0.05) equal to $=6.35$. Through the attached aspects, the presence of the agreement percentage that ranges between $(66.44 \%$ and $86.42 \%)$ and the chi-square came at $(85.36 \%)$, which is a significant percentage and this is consistent with both (Al Hayy 2017, Al Mulla 2020, Yahyaoui 2017, Koumi 2018, Al-Khail 2015). This is due to the progress towards the use of technology at the present time during the pandemic. 


\section{The second question:}

What are the human requirements with the challenges of E-learning in light of the pandemic?

Table No. (3)

Human requirements of E-learning in light of the Corona pandemic.

$\mathrm{N}=132$

\begin{tabular}{|c|c|c|c|}
\hline $\begin{array}{l}\text { Chi- } \\
\text { square }\end{array}$ & $\begin{array}{l}\text { Standard } \\
\text { Deviation }\end{array}$ & $\begin{array}{l}\text { Arithmetic } \\
\text { mean }\end{array}$ & Human Requirements \\
\hline \multirow{7}{*}{85.36} & 0.67 & 2.34 & $\begin{array}{l}\text { 1. Participating effectively in the } \\
\text { educational process. }\end{array}$ \\
\hline & 0.34 & 2.36 & $\begin{array}{l}\text { 2. Electronic or face-to-face } \\
\text { communication. }\end{array}$ \\
\hline & 0.58 & 2.87 & $\begin{array}{l}\text { 3. Dealing with information } \\
\text { technology. }\end{array}$ \\
\hline & 0.90 & 2.14 & $\begin{array}{l}\text { 4. Cooperation and interaction } \\
\text { with the teacher and his } \\
\text { colleagues, especially in training } \\
\text { workshops }\end{array}$ \\
\hline & 1.25 & 2.65 & $\begin{array}{l}\text { 5. Designing } \\
\text { electronic tests and assessment } \\
\text { tools. }\end{array}$ \\
\hline & 0.67 & 2.64 & $\begin{array}{l}\text { 6. Transitioning from traditional } \\
\text { education to E-learning. }\end{array}$ \\
\hline & 0.34 & 2.57 & $\begin{array}{l}\text { 7. Provide direct feedback to the } \\
\text { teacher. }\end{array}$ \\
\hline
\end{tabular}

It is evident from Table No. (3) and Fig. No. (3) show * The value of chi-square $=85.36 *$ chi-square tabular at a degree of freedom (5) and an error ratio $\geq(0.05)$ equal to $=6.35$ through the aspects attached to it on the existence of the agreement percentage which ranges between $(55.41 \%$ and $82.32 \%)$ and came to chi-square at $(75.36 \%)$, which is a significant percentage. This is consistent with (Ghazi 2020, Al Hayy 2017, Basilaia 2020). This is due to the cognitive progress, the cultural explosion of knowledge and digital transformations of that stage and the development towards the use of those human requirements in the pandemic. 


\section{The third Question:}

What are the contents of a learning management system in light of the Corona pandemic?

Table No. (4)

The contents of a learning management system in light of the Corona pandemic

\begin{tabular}{|c|c|c|c|}
\hline $\begin{array}{l}\text { Chi- } \\
\text { square }\end{array}$ & $\begin{array}{l}\text { Standard } \\
\text { Deviation }\end{array}$ & $\begin{array}{l}\text { Arithmetic } \\
\text { mean }\end{array}$ & $\begin{array}{c}\text { The contents of a learning } \\
\text { management system }\end{array}$ \\
\hline \multirow{7}{*}{75.36} & 0.33 & 2.18 & $\begin{array}{l}\text { 1. Email: This tool allows teachers } \\
\text { and learners registered within the } \\
\text { course and course professor to send } \\
\text { and receive mail messages between } \\
\text { them }\end{array}$ \\
\hline & 0.33 & 2.16 & $\begin{array}{l}\text { 2. Discussion Tool: The discussion } \\
\text { tool allows students registered in the } \\
\text { course to exchange views on topics } \\
\text { related to the course. }\end{array}$ \\
\hline & 0.35 & 2.08 & $\begin{array}{l}\text { 3. Simultaneous communication: any } \\
\text { type of communication that takes } \\
\text { place in real time and does not always } \\
\text { require a learning management } \\
\text { system }\end{array}$ \\
\hline & 0.35 & 2.08 & $\begin{array}{l}\text { 4. Providing a sufficient number of } \\
\text { modern computer devices equipped } \\
\text { with data show and connected to the } \\
\text { Internet. }\end{array}$ \\
\hline & 0.93 & 3.90 & $\begin{array}{l}\text { 5. Providing an electronic course for } \\
\text { each physical education subject } \\
\text { provided on the blackboard program } \\
\text { and the Zoom program. }\end{array}$ \\
\hline & 0.09 & 3.30 & $\begin{array}{l}\text { 6. School content management } \\
\text { system for physical education } \\
\text { courses. }\end{array}$ \\
\hline & 0.27 & 2.35 & $\begin{array}{l}\text { 7. A full understanding of the } \\
\text { characteristics, needs and } \\
\text { requirements of students of all levels. }\end{array}$ \\
\hline
\end{tabular}

It is evident from Table No. (4) and Fig. No. (4) that * The value of chi-square $=75.36 *$ chi-square tabular at a degree of freedom (5) and an error ratio $(0.05)$ equal to $=6.35$ through the aspects attached to it on the existence of the agreement percentage Which ranges between $(60.41 \%$ and $80.32 \%)$ and came to chi- square by $(75.36 \%)$, which is a 
significant percentage. This is in agreement with (Koumi 2018, Al Hayy 2017, Berg, 2020, Basilaia 2020, Al-Mulla, 2020, Nofal 2015, Yahyaoui, 2017) This is due to the development in the systematic design of the scientific course and how to communicate through digital transformations in light of electronic challenges and the shadow of the Corona pandemic.

\section{The Fourth Question:}

1. What is the level of physical education teachers' interaction with the challenges of e-learning in light of the Corona pandemic?

Table No. (5)

The level of interaction of physical education teachers with the challenges of E-learning

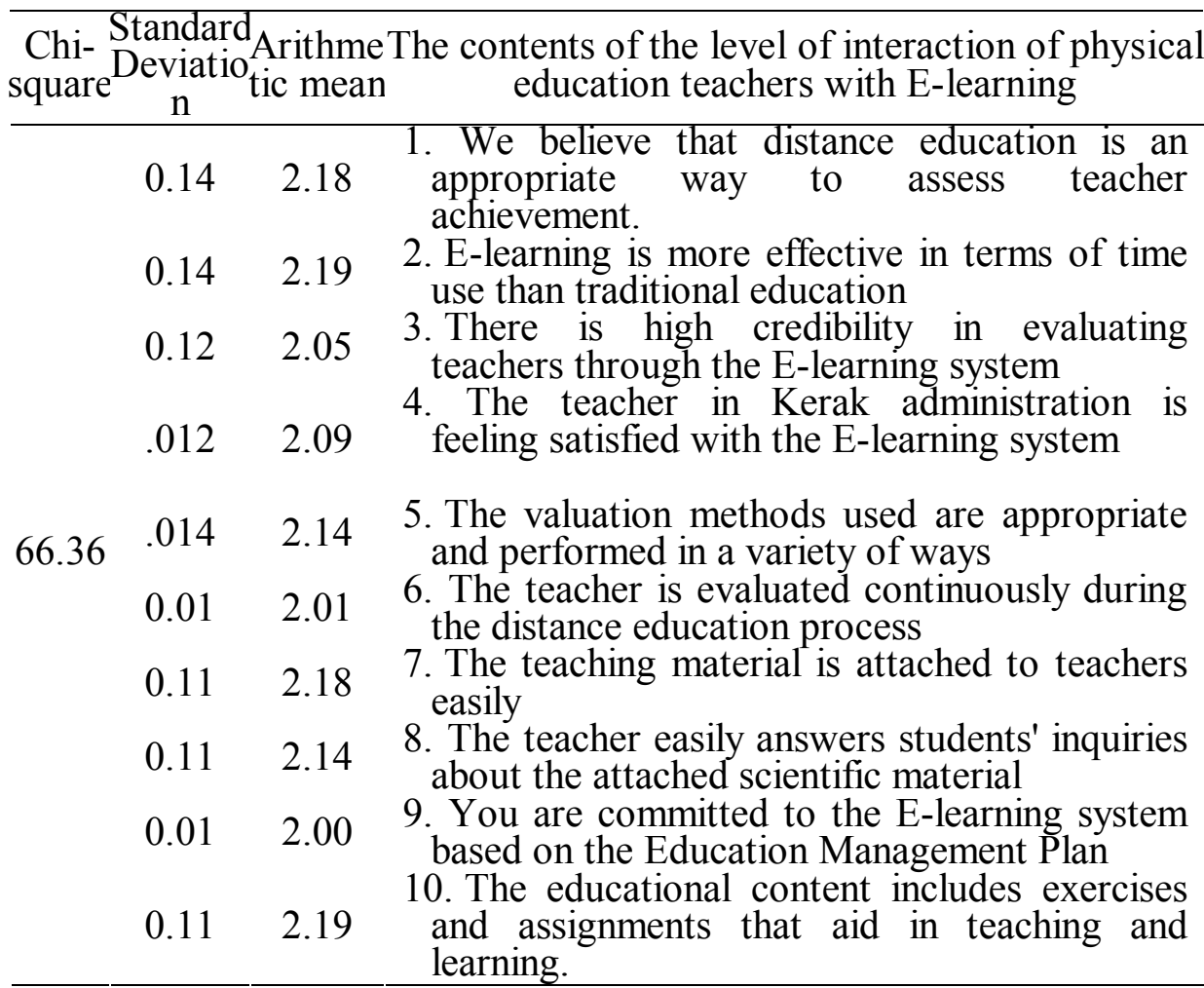

The results show that $*$ the value of chi-square $=66.36 *$ chi-square tabular at a degree of freedom $(5)$ and an error ratio $\geq(0.05)$ equal to $=$ 6.35 through the aspects attached to it on the existence of the agreement percentage that ranges between $(66.01 \%$ and $76.42 \%)$. The chi- square came with $(66.36 \%)$, which is a significant percentage, and this is consistent with (Al Hayy 2017, Al Mulla 2020, Yahyaoui 2017, Koumi 2018, Al Khail 2015, Ghazi 2020, Basilaia 2020, Berg 2020, 

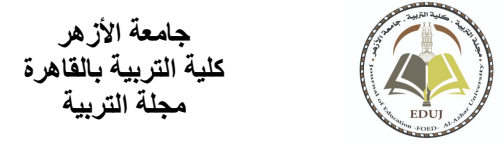

Koumi 2018, Yulia 2020). This is due to the progress towards the use of technology at the present time.

\section{Conclusion}

1. Applying the level of physical education teachers' interaction with the challenges of E-learning in light of the Corona pandemic.

2. Implementing the contents of a learning management system with the challenges of E-learning in light of the Corona pandemic.

3. Applying technology requirements with the challenges of Elearning in light of the Coronavirus pandemic.

4. Applying the human requirements with the challenges of Elearning in light of the Corona pandemic.

7.1 Recommendations:

1. E-learning is continuous in the light of Corona pandemic

2. The application of blended education in the teaching and learning process.

3. Application of electronic challenges in the teaching and learning processes. 


\section{References}

Aba Al-Khail, Abdel-Wahhab. (2015). The reality of King Saud University students 'use of the e-learning management system (Moodle). Master Thesis. Yarmouk University.

Abdel Hay, Ramzi. (2017). Distance education in the Arab world and the challenges of the twenty-first century. Cairo: 1st floor, The Anglo Library.

Allam, Al-Kamel. (2019). Obstacles to e-learning in Saudi universities: Applying to King Abdulaziz University in Jeddah. www.kau.edu.sa.

Al-Mulla, Faisal. (2020). Physical education and the Corona pandemic. Retrieved from https://www.alayam.com/Article/sportarticle/416610/Index.html

Asim, J. a. (2020). A proposed vision from the perspective of blended education and for teaching physical education in the context of the quality of the process. Jordan: Journal of Educational Studies at the University of Jordan.

Basilaia, G. \&. (2020). Transition to Online Education in Schools during a SARS-CoV-2 Coronavirus (COVID-19) Pandemic in Georgia. Pedagogical Research, 5(4), em0060. https://doi.org/10.29333/pr/7937 Retrieved, 27/5/2020.

Berg, G. S. (2020). Distance learning. Britannica. https://www.britannica.com/topic/distance-learning.

Boukahous, Khaled. (2020). The future of e-learning in light of and after the Corona pandemic. Manama: http://www.akhbaralkhaleej.com/news/article/1217814.

Ghazi, Muhammad, Rababa'a, Jamal. (2020). Digital transformations in physical education science. Jordan: Dijlah House for Publishing and Distribution.

Hamdan, Helmy. (2020). E-learning in the time of corona between challenges and solutions. Alf Publishing and Distribution House: Algeria.

https://www.weforum.org. (2020, 11 27). coronavirus-educationglobal-covid19-online-digital-learning/. Retrieved from lagenda/2020/04/coronavirus-education-global-covid19-onlinedigital-learning/

Koumi, J. (2018). - Designing Educational Video and Multimedia for Open and Distance Learning.,. Routledge, England.

Novell, Saifi. (2015). The trend of faculty members at Al-Quds Open University towards electronic education and its relationship to self-efficacy, an unpublished master's thesis, Islamic University - Gaza, Palestine 
Shehata and et al. (2010). The Effectiveness of a Proposed Program in Providing Middle School Pupils with Some E-Learning Skills and Developing the Attitude Toward It, The Scientific Journal, Faculty of Education, Assiut University, Volume (26), Issue (1), pp. 532-p.573.

World Health Organization. (2020). Coronavirus (Covid-19). Retrieved from https://www.who.int/en/emergencies/diseases/novelcoronavirus.

Yahya, Ibrahim, (2017). The impact of technology for a scientist and communication on the educational process. Jordan: Al-Yazurdi Scientific House.

Yulia, H. (2020). - Online Learning to Prevent the Spread of Pandemic Corona Virus in. 11(1. Indonesia. ): ETERNAL (English Teaching Journal. 